\section{DISEASES OF THE NOSE AND THROAT}

By Sir StClair Thomson, M.D., F.R.C.P., F.R.C.S., LL.D. Revised by V. E. Negus, D.Sc., M.S., F.R.C.S., with the assistance of G. H. Bateman, M.A., B.M., B.Ch., F.R.C.S. Sixth edition. Pp. xvi + ro40, with 353 illustrations and 46 plates, some in colour. London: Cassell \& Co. Ltd. 1955. 90s.

Everyone who studies rhinology and laryngology knows this book; such is its fame and authority. Many hold views on how it ought to be improved upon, but critics will find that this new edition is, on the whole, a very conservative revision of the previous one.

The book is bigger by 36 pages, and there are excellent new operative details and diagrams describing the transpalatal approach to the nasopharynx, surgical relief of paralytic glottic stenosis, laryngectomy, pharyngectomy, and block dissection of neck glands. The international nomenclature of the bronchial tree has been adopted.

If one could open this new edition as a complete stranger to the book, perhaps the first reaction would be of delight at the excellent paper and large, clear print. Then the pictures and diagrams would claim one's admiration, for they are of a very high standard. The ample index, and the long list of references at the end of each chapter will be valuable aids to ' armchair research.' As any good book must do, this book whets the appetite for reading by its very form and presentation.

Thus beguiled, the reader embarks upon the text. In a short review it is impossible to dissect such a work page by page, and minor criticisms might seem only to be of the destructive variety. As a fund of basic knowledge this text is unsurpassed and will undoubtedly maintain its position for a long time yet to come. The authors, however, hold in trust the responsibility of deciding when the time is ripe for a more drastic pruning and revision than they have thought desirable this time.

\section{J.G.}

\section{MODERN TREATMENT YEAR BOOK, 1956}

Edited by Sir Cecil Wakeley, Bt., K.B.E., C.B., LL.D., M.Ch., D.Sc., F.R.C.S., F.R.S.E., F.R.S.A., F.A.C.S., F.R.A.C.S. Pp. viii +344 , with 47 illustrations. London: Bailliere, Tindall \& Cox, Ltd. 1956. 25 s.

This book contains a series of short articles written primarily for the general practitioner and representing all branches of clinical medicine. For the most part the standard is exceptionally high, the authors obviously having taken pains to describe fundamental points in straight-forward language. Especially well written are the sections on antibiotics and the treatment of portal hypertension.
One article requiring criticism is that on biliary obstruction. We are told that in the cause of this condition operative trauma to the bile ducts is second in frequency to gallstones and is commoner than pressure on the ducts by primary or secondary malignant disease. This may be true of one or two of the larger American clinics, to which operative injuries are referred on a continental scale, but such cases are by far the least common of the three in the average British hospital. The writer of this section also misinterprets Courvoisier's law. So clear and accurate are many contributions, however, they will make worth-while reading not only for general practitioners but also for those with special experience of the subject matter.

H.L.B.

\section{OUTLINE OF ORTHOPAEDICS}

By John Crawford Adams, M.D., F.R.C.S. Pp. vii + 423. Edinburgh: E. \& S. Livingstone Ltd. 1956. 32s. $6 \mathrm{~d}$.

For some years now there has been a great demand in Britain for a short textbook of orthopaedic surgery. The needs of the practitioner and postgraduate student were largely filled by the publication in 1949 of Wiles' 'Essentials of Orthopaedics,' but the undergraduate was still largely obliged to rely on verbal instruction for his introduction to the mysteries of varus and valgus, ankylosis and arthrodesis, joint stability and joint stiffness, and the whole range of ideas and terms peculiar to clinical orthopaedics.

Following the introductory paragraphs on clinical methods and a general survey of orthopaedic problems, the author covers in outline the whole range of orthopaedic afflictions, region by region. Each disorder of the trunk, upper and lower limbs is serially analysed by clinical features, pathology, diagnosis and treatment.

The illustrations are lavish and informative. One-half of the three hundred figures consists of clinical photographs and radiographs; the remaining half are line drawings with the merit of simplicity and direct instruction which the student will appreciate.

The author's primary intention ' . . . to help students who are studying for the qualifying examinations,' has undoubtedly been fulfilled. It is, therefore, perhaps unfair to chide him with an excessively didactic approach. The reviewer would have preferred a more thought-provoking course between dogmatism and scepticism, but this remains common to all textbooks for the undergraduate medical student. But Crawford Adams has produced a textbook for which successive generations of students will thank him.

The general production of the book is of an excellence to be expected when the assistant editor of the Fournal of Bone and Foint Surgery combines with Messrs. E. \& S. Livingstone Ltd., and we 
may look forward to its companion volume on fractures which we are promised in the preface.

A.W.L.K.

\section{ESSENTIALS OF FORENSIC MEDICINE}

By C. J. Polson, M.D., F.R.C.P. Pp. $x+56 r$. London: English Universities Press. 1955. 30s.

This is an entirely new work on forensic medicine and differs in many respects from other textbooks on the subject. Professor Polson is a doctor, barrister and a scholar, and each branch of his learning is reflected in his book. As a doctor he has written with authority on the medical aspects of crime, emphasizing those which interest him most, such as mechanical asphyxia and identification. As a barrister he has introduced a great deal more law than is usual into his text, thus increasing its value and interest to members of the legal profession. As a scholar he has written 539 pages on forensic medicine, less toxicology, without an illustration, his descriptive powers being such that illustration is almost superfluous, and has combed the world's forensic literature, not only augmenting his own personal experiences, but supplying very many valuable references to be found in no other British book on the subject. Not only do his references come from British, American and Continental textbooks and literature, but also from biographies, the Penguin series, and even the daily Press. In the latter case references would be of more value if he had referred to subsequent articles on the cases which have appeared in legal or medical publications where they are readily available.

In his preface Professor Polson says his book is primarily intended for students of law and medicine. One feels that, despite the author's clear presentation, it is too large and detailed a book for the undergraduate, but for those who practise forensic medicine Professor Polson's new book, besides being a pleasure to read, will also serve as a most valuable source of reference.

\section{A.K.M.}

\section{BROMPTON HOSPITAL REPORTS VOL. XXIII, 1954}

Pp. ix +326 , illustrated. Aldershot: Gale and Polden. 1956. I 5 s.

Twenty articles are reprinted in this new edition of the Brompton Hospital Reports. These cover a very wide range of diseases of the heart and lungso and included is Dr. Paul Wood's valuable 'Appreciation of Mitral Stenosis.' This is a clinica study of 300 patients with mitral valve disease half of these were operated upon. There are four articles on chronic bronchitis. These illustrate clinical, pathological and bacteriological features of this condition which, although the commones $\tilde{5}_{5}^{+}$ chest disease, has had extraordinarily little attention paid to it. This publication is recommended to all interested in the management of chest diseases.

L.L.B.

\section{THE TREATMENT OF RENAL FAILURE: THERAPEUTIC PRINCIPLES IN THE MANAGEMENT OF ACUTE AND CHRONIC URAEMIA}

By John P. Merrill, M.D. Pp. $x+238$, with 3 施 illustrations. London: Grune \& Stratton Inc.. I 955 . \$6.75.

Dr. John Merrill has written an excellent account of the therapeutic principles governing the manage-? ment of acute and chronic uraemia. There is $a_{c}$ clear description of normal renal function and body electrolyte balance, followed by an account of thed signs and symptoms of renal failure, of the courge of acute and chronic uraemia and of the indicatiogser for treatment by extra-renal routes. His approach. that of the experienced and sensible clinician wo is also a physiologist, is admirably balanced and his style is clear and most readable. There is an account of the work done in the author's depart-@ ment at the Peter Bent Brigham Hospital on theo transplantation of the human kidney. There are 302 references and a good index.

Several controversial points, such as the signifi-3 cance of the E.C.G. in potassium disturbances and the use of fat in the dietary management of acute renal failure, are sensibly discussed without prejudice. Possibly the author slightly over-emphasizes? the importance of interstitial oedema of the kidneyo in uraemia. The original concept of 'uraemic 3 . lung' was based on pathological evidence, and the? absence of a distinctive radiological appearance 3 does not rule out its existence. (There is no reference to Doniach's paper, published in America.)

Estimation of P.A.H. extraction does not rule out the possibility of tubular back diffusion causing erroneously low values for P.A.H. clearance in N acute renal failure. But these are minor criticisms of an admirable little book. 